\title{
Methylation of DNA
}

\author{
MARVIN GOLD, MALGOLM GEFTER, RUDOLPH HAUSMANN, \\ and JERARD HURWITZ
}

From the Departments of Molecular Biology and Developmental Biology and Cancer, Albert Einstein College of Medicine, Bronx, New York. Dr. Hausmann's present address is Graduate Research Center of the Southwest, Dallas, Texas

\begin{abstract}
The methylated bases of DNA are formed by the transfer of the methyl group from S-adenosylmethionine to a polynucleotide acceptor. This transfer is catalyzed by highly specific enzymes which recognize a limited number of available sites in the DNA. The mechanism for the recognition is presently unknown. In some instances, there is evidence that other cellular components, such as lipopolysaccharides, can influence the methylation reaction. Certain bacteriophages induce new methylases upon infection of their hosts. Phage T3 is unique in establishing an environment in which methylation of neither the phage nor the host nucleic acid can occur. By superinfecting T3infected cells with other phages, the latter can be obtained with methyl-deficient DNA. Although a great deal is known about the enzymology of the methylation reaction, and there appears to be a strong correlation between the in vitro and in vivo reactions, studies in which DNA is either supermethylated or totally unmethylated have not yielded any insight as to what the possible function of the methylated bases may be.
\end{abstract}

Our knowledge of biological macromolecules has accumulated so rapidly in recent years that we are no longer content with asking questions only about their structure, their biosynthesis, or their functions. Indeed, it is remarkable that today we often have a clearer picture of the genetics and the complex regulatory machinery of these molecules than we do of their identity.

To study the mechanisms whereby the replication and function of DNA are regulated is, of course, a unique task, since we now, in a sense, ask, "What exercises genetic control over the genetic material itself?" Fifteen years ago (1), a new base, 5-methylcytosine, was discovered in the DNA of higher plants and animals; several years later another new base, 6-methylaminopurine, was discovered in the DNA of certain bacteria and bacteriophage (2).

Although until recently there was no known pathway for the biosynthesis of these so-called "trace bases," there was speculation that they might be involved in some sort of code or recognition system. Two important facts have led to the elucidation of the biosynthesis of the methylated bases in DNA: The 
discovery of the glucosylation of bacteriophage DNA by Dr. Kornberg and his colleagues (3), and the methylation of soluble RNA, discovered by Dr. Borek of Columbia University and his colleagues (4).

Both of these enzymatic reactions occur at the polynucleotide level. In our laboratory, we have found that DNA is also methylated at the polynucleotide level (5), and it is this reaction which will form the basis of this discussion. The findings which will be presented are the result of work carried out over the last two or three years and are a summary of our present knowledge about the methylation of DNA.

T A B L E I

REQUIREMENTS FOR DNA METHYLATION

\begin{tabular}{lc}
\hline \multicolumn{1}{c}{ Additions } & $\begin{array}{c}\text { 4C-CH} \text { groups } \\
\text { incorporated }\end{array}$ \\
\hline Complete system & $\mu \mu$ moles \\
- Methyl-deficient $E$. coli DNA & 179 \\
- 2-Mercaptoethanol & $<1$ \\
- 2-Mercaptoethanol $+p$-hydroxymercuribenzoate & 26 \\
+ EDTA & 18 \\
+ Mg & 201 \\
- Methyl-deficient $E$. coli DNA, + normal $E$. coli DNA & 187 \\
- Methyl-deficient $E$. coli DNA, $+E$. coli strain W DNA & $<1$ \\
\hline
\end{tabular}

The complete system $(0.25 \mathrm{ml})$ contained Tris buffer, pH 8.0, $25 \mu$ moles; $\mathrm{MgCl}_{2}, 1 \mu$ mole; 2 -mercaptoethanol, $4 \mu$ moles; ${ }^{14} \mathrm{C}$-methyl-labeled S-adenosyl-L-methionine ( 1.5 to $3 \times 10^{7} \mathrm{CPM}$ per $\mu$ mole), $10 \mathrm{~m} \mu$ moles; and methyldeficient $E$. coli DNA, $100 \mathrm{~m} \mu$ moles. Where indicated, $p$-hydroxymercuribenzoate, EDTA, and $\mathrm{MgCl}_{2}$ were added to final concentrations of $2 \times 10^{-4}$ $\mathrm{M}, 8 \times 10^{-3} \mathrm{M}$, and $4 \times 10^{-8} \mathrm{M}$, respectively. In the last two reactions, 100 $\mathrm{m} \mu$ moles of nucleotide residues as DNA were added as indicated. All reaction mixtures contained $2.5 \mu \mathrm{g}$ of protein of an ammonium sulfate II preparation of the DNA methylase, and the reactions were terminated after 30 $\min$ at $37^{\circ} \mathrm{C}$.

The equation shown in Scheme I represents the reaction whereby the methyl group of S-adenosylmethionine, the methyl donor, is transferred under enzymic catalysis to DNA, the methyl group acceptor.

Scheme I

DNA $+{ }^{14} \mathrm{C}_{-}-\mathrm{CH}_{3}$-S-adenosylmethionine $\rightarrow{ }^{14} \mathrm{C}$-DNA + S-adenosylhomocysteine

By specifically labeling the methyl group with radioactive ${ }^{14} \mathrm{C}$, this reaction can easily be followed by measuring the formation of acid-insoluble radioactivity. The two products which can be formed are 6-methylaminopurine and 5-methylcytosine, and the reaction is apparently irreversible (6).

An enzyme fraction has been extensively purified from Escherichia coli strain 
W, which has the properties shown in Table I. The complete system consists of buffer, a thiol reagent, S-adenosylmethionine, and an acceptor DNA. Metal ions are not required for this reaction, nor do they stimulate the activity of the enzyme. In this case, the DNA substrate was methyl-deficient, a condition which was brought about by growing a methionine-requiring

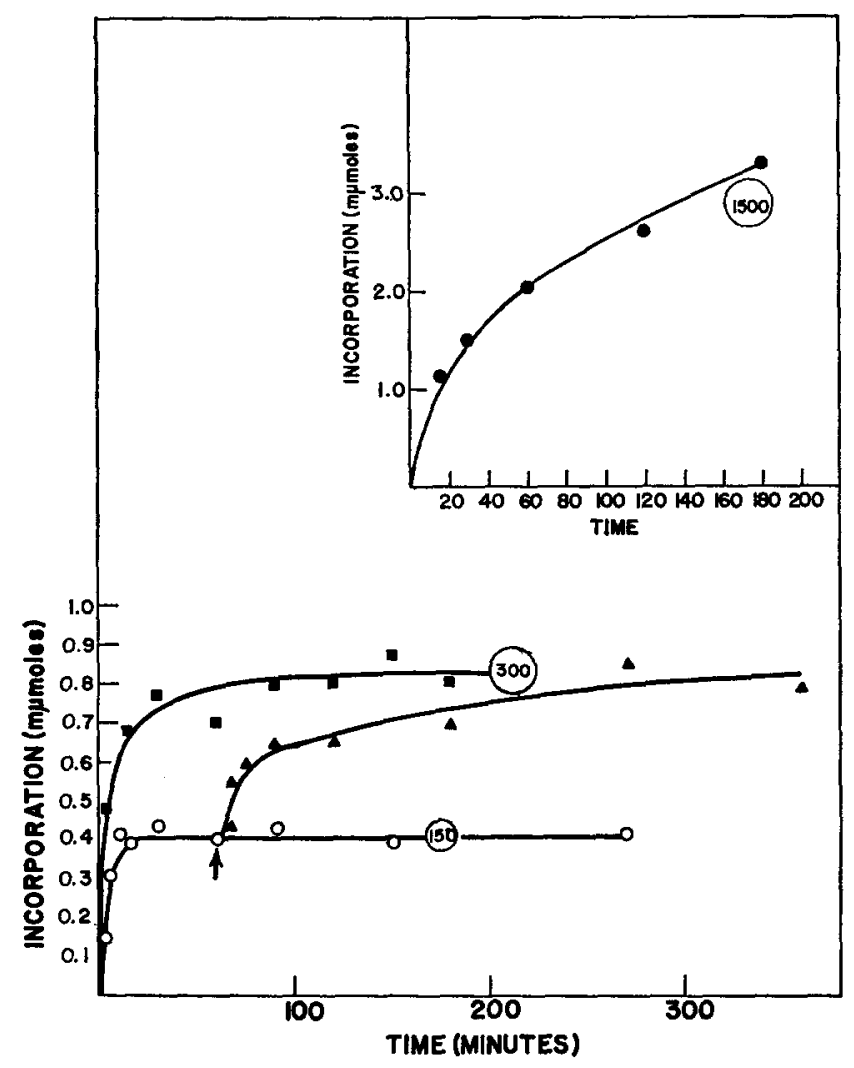

FIgURE 1. Kinetics of methylation with varying amounts of DNA. Reaction mixtures (1.25 ml) contained Tris buffer, $\mathrm{pH} 8.0,50 \mu$ moles; $\mathrm{MgCl}_{2}, 5 \mu$ moles; 2-mercaptoethanol, $10 \mu$ moles; ${ }^{14} \mathrm{C}$-methyl-labeled S-adenosylmethionine $\left(1.4 \times 10^{7} \mathrm{cPM}\right.$ per $\mu$ mole), $50 \mathrm{~m} \mu$ moles, and $21.2 \mu \mathrm{g}$ of protein of an ammonium sulfate enzyme fraction. Methyl-deficient $E$. coli DNA was added as follows: lowest curve (open circles), $150 \mathrm{m \mu}$ moles of deoxyribonucleotide residues; middle curve (solid squares), 300 mumoles; and the top curve (solid circles), $1500 \mathrm{~m} \mu$ moles; the reaction mixtures were incubated at $37^{\circ}$ at the indicated times, $0.05 \mathrm{ml}$ aliquots were removed, and the acid-insoluble radioactivity was determined. In the experiment illustrated in the lowest curve (designated 150), the reaction mixture was divided into two $0.50 \mathrm{ml}$ portions at $60 \mathrm{~min}$, as indicated by the arrow. To one were added $60 \mathrm{~m} \mu$ moles of nucleotide residues as methyl-deficient $E$. coli DNA (solid triangles), and to the other were added $8.5 \mu \mathrm{g}$ of protein of ammonium sulfate II enzyme fraction (open circles). Incubation was then continued and assayed as above. All values have been corrected for the slight changes in volume involved. 

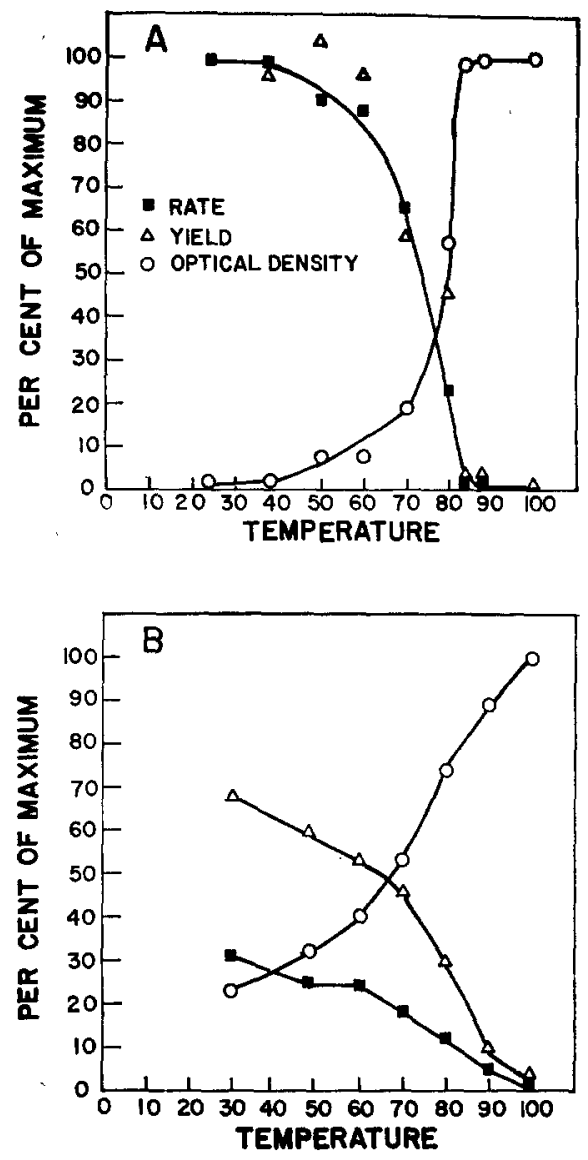

Figure 2. $A$, methylation of methyldeficient $E$. coli DNA heated to various temperatures. Reaction mixtures for the assay of methylation on the heated DNA samples were similar to those described in Table I, except that 5.3 $\mu \mathrm{g}$ of an ammonium sulfate II fraction were used. For rate determinations (solid squares), a $15 \mathrm{~min}$ incubation was employed; the $100 \%$ or maximum value obtained with untreated DNA was $175 \mu \mu$ moles of methyl groups incorporated in $15 \mathrm{~min}$. For the determination of the extent of the reaction (open triangles), $13.3 \mu \mathrm{g}$ of ammonium sulfate II enzyme fraction were used and the incubation period was $60 \mathrm{~min}$. Under these conditions the maximum extent was $355 \mu \mu$ moles of methyl groups incorporated. Absorbance at 260 $\mathrm{m} \mu$ (open circles) showed an increase of $26 \%$ above $85^{\circ} . B$, methylation of methyldeficient $E$. coli DNA after heating and renaturation.

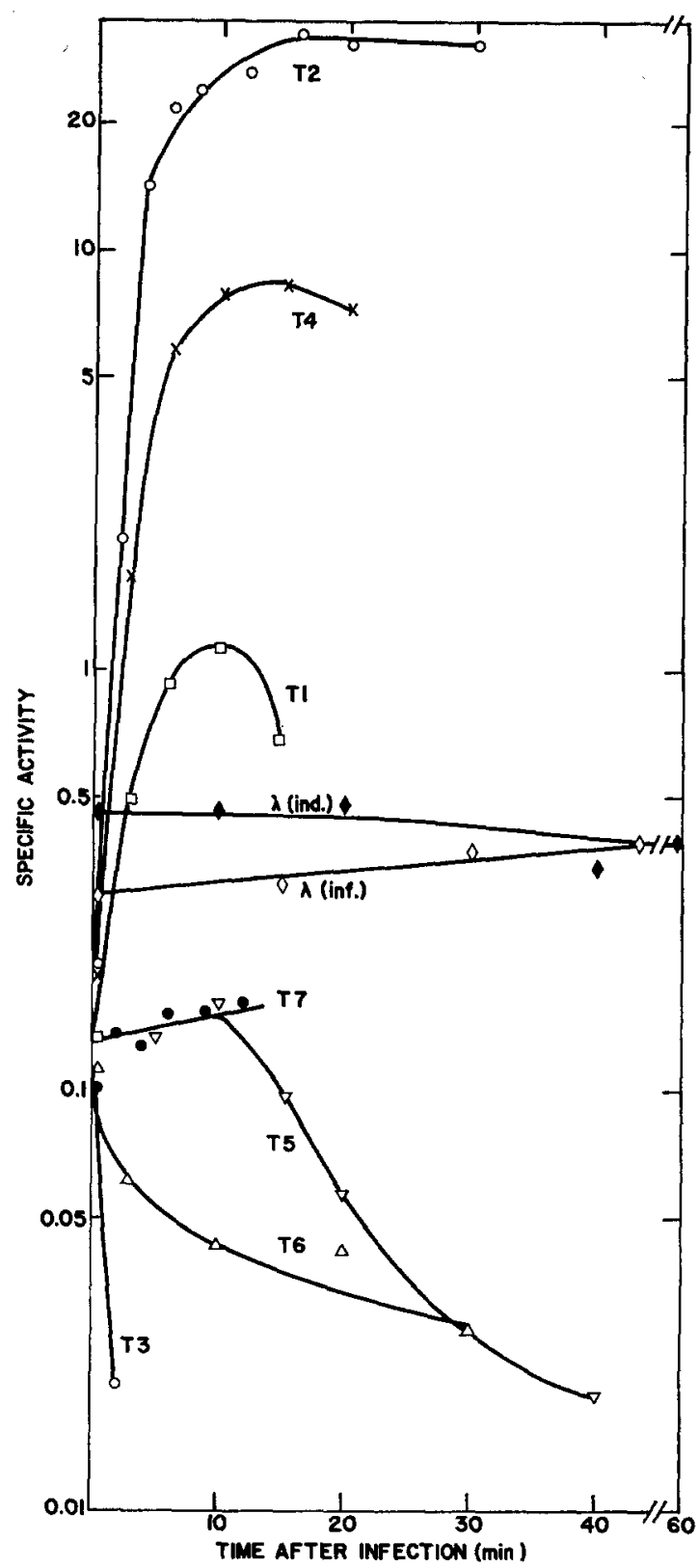

Figure 3. DNA methylase activity in cell-free extracts of phage-infected cells as a function of time after infection. The assays were carried out as previously described, using $M$. lysodeikticus DNA as a methyl group acceptor. The host was $E$. coli B, except for phage $\lambda$ where the infected host was $E$. coli W3104. A time course after $\lambda$-prophage induction is also shown. At time 0 , mitomycin $\mathrm{C}(1 \mu \mathrm{g} / \mathrm{ml})$ was added to an exponentially growing culture of $E$. coli W3104 $(\lambda)$. Lysis occurred after about $100 \mathrm{~min}$. All the above infections were performed at $37^{\circ} \mathrm{C}$. 
strain of Escherichia coli in the absence of this amino acid (6). The reaction is completely dependent on the presence of S-adenosylmethionine; several other biological methyl group donors tested were inactive. Not only is native methyl-deficient DNA required here, but when normal DNA (that is, DNA extracted from the very same strain of this organism, but grown in an excess of methionine) is substituted, no reaction occurs.

This result implies that there are available to the enzyme only a certain number of sites capable of receiving methyl groups. This is shown more

T A B L E I I

METHYLATION OF DNA POLYMERASE PRODUCTS

\begin{tabular}{|c|c|c|c|}
\hline DNA & Treatment & $\begin{array}{c}\text { New DNA } \\
\text { formed }\end{array}$ & $\begin{array}{l}\text { Extent of } \\
\text { methylation }\end{array}$ \\
\hline & & $\begin{array}{c}\text { Mumoles } \\
\text { nucleotides }\end{array}$ & $\begin{array}{c}\text { Humoles }{ }^{14} \mathrm{C}- \\
\mathrm{CH}\end{array}$ \\
\hline \multirow[t]{3}{*}{ T2 (90) } & DNA polymerase system & 68,000 & 78 \\
\hline & Omit dATP & - & 2 \\
\hline & None & - & $<1$ \\
\hline E. coli $\mathrm{K} 12$ & DNA polymerase system & 92,000 & 436 \\
\hline $58-161$ & Omit dATP & - & $<2$ \\
\hline$(140)$ & None & - & $<2$ \\
\hline
\end{tabular}

These experiments were carried out in two stages. For replication with DNA polymerase, reaction mixtures $(0.93 \mathrm{ml})$ contained Tris buffer, $\mathrm{pH} \mathrm{8.4,50}$ $\mu$ moles; $\mathrm{MgCl}_{2}, 4 \mu$ moles; 2-mercaptoethanol, $8 \mu$ moles; T2 or Escherichia coli DNA, 90 or $140 \mathrm{~m} \mu$ moles of nucleotide residues, respectively; dATP, $150 \mathrm{~m} \mu$ moles; dCTP, $140 \mathrm{~m} \mu$ moles ; dGTP, $170 \mathrm{~m} \mu$ moles; dTTP, $245 \mathrm{~m} \mu$ moles ; and DNA polymerase, $1.5 \mu \mathrm{g}$ of protein. Similar reaction mixtures, but containing ${ }^{14} \mathrm{C}$-dATP $\left(6.5 \times 10^{5} \mathrm{GPM}\right.$ per $\mu$ mole), were also included to determine the extent of new DNA synthesis. After incubation at room temperature for $16 \mathrm{hr}$, the extent of methylation was determined by adding 2-mercaptoethanol, $16 \mu$ moles; ${ }^{14} \mathrm{C}$-methyl-labeled S-adenosylmethionine, $40 \mathrm{~m} \mu$ moles; and 3.2 units of an ammonium sulfate II DNA-methylating enzyme fraction. After $3 \mathrm{hr}$ at $37^{\circ} \mathrm{C}$, the reaction mixtures were treated as previously described.

clearly in Fig. 1. The main conclusion to be drawn is that after the reaction has come to a halt, the addition of more enzyme is without effect (7). However, if an equivalent amount of DNA is again added at this point, the reaction begins again and then halts, but only after a further 0.4 millimicromole of methyl group has been incorporated. It can also be seen that the final yield or the extent of the methylation reaction is proportional to the concentration of the DNA substrate. A DNA acceptor, then, can be characterized by the extent to which it can be methylated by this enzyme in vitro. We have investigated the properties of the DNA which determine this yield.

The results in Fig. 2 represent an experiment in which the ability of DNA to act as a methyl group acceptor was measured after the DNA had been 
heated at various temperatures. The steep rise in the optical density of the DNA solution indicates that the helix coil transition has occurred. As this DNA melts, both the rates and the yield of methylation decrease until at about $85^{\circ} \mathrm{C}$ the reaction is virtually abolished. If heated DNA, in which no methylation occurs, is slowly cooled under conditions favoring renaturation, it again becomes capable of accepting methyl groups (7).

We conclude, therefore, that the secondary structure of the DNA is an important parameter. However, not all native DNA's are methyl acceptors, so that presumably the primary structure, i.e., the base sequence must be a determining factor. We have attempted to illustrate this in the experiment

\begin{tabular}{lccr}
\multicolumn{4}{c}{ T A B L E I I I } \\
\multicolumn{4}{c}{ METHYLATION OF VARIOUS DNA'S } \\
\hline Bource composition & Extent & 6MA/5MC \\
& A+T/G+C & \% of total bases & \\
E. coli B & 1.0 & 0.21 & $<0.05$ \\
E. coli $\mathrm{K} 12$ & 1.0 & 0.65 & 1.73 \\
$\lambda$ & 1.0 & 0.08 & 0.61 \\
Mb. phlei & 0.48 & 5.8 & 1.63 \\
Rat brain & 1.4 & 0.50 & 0.36 \\
Wheat germ & 1.2 & 0.27 & 2.19 \\
\hline
\end{tabular}

Reaction mixtures were as previously described, except that a different DNA was used in each case. When methylation had come to a halt, aliquots were removed, acid precipitated, hydrolyzed, and analyzed by paper chromatography for base composition.

summarized in Table II. In this example, two DNA's, bacteriophage T2 and a particular strain of Escherichia coli K12 (both of whose DNA's do not accept methyl groups with the $W$ enzyme), have been partially replicated with the enzyme DNA polymerase (8). There is significant methylation of the new DNA which has been formed. That the DNA polymerase itself is not altering the properties of the template is shown by the control where one of the necessary four deoxyribonucleoside triphosphates has been omitted. These results can be interpreted to mean that, in vivo, certain available sites for methylation are filled. When the DNA's are extracted and exposed to this particular methylase, no further sites are recognized, and since methylation occurs at the polynucleotide level, the DNA polymerase products containing the proper sequences still have empty methylatable sites.

Let us now examine in more detail the products of methylation. DNA preparations from a great variety of sources have been examined as substrates for the $E$. coli W methylase and these studies have uncovered another property of this system; that is, that different DNA's can be characterized by the extent to which they can be methylated in vitro by a particular enzyme. 
This is indicated in Table III as the per cent of the total bases that are methylated. The $E$. coli $\mathrm{K} 12$ used here is a different strain than that shown previously, and as can be seen, it is an acceptor of methyl groups. The difference between these strains is an example of a further complexity which will be discussed later. Also shown in Table III is the ratio of the amounts of 6methylaminopurine to 5-methylcytosine formed in each case. This value is also characteristic of a given DNA.

T A B L E I V

METHYLATION OF DNA

\begin{tabular}{|c|c|c|c|c|c|c|c|c|c|}
\hline \multirow{2}{*}{ Enzyme source } & \multicolumn{9}{|c|}{ Source of DNA } \\
\hline & $\begin{array}{l}\text { Starved } \\
\text { E. coli }\end{array}$ & $\begin{array}{l}\text { Normal } \\
\text { E. coli }\end{array}$ & $\begin{array}{c}M . \\
\text { lysodtikticus }\end{array}$ & $\begin{array}{l}\text { C. diph } \\
\text { theriat }\end{array}$ & $\begin{array}{l}\text { L. del- } \\
\text { bruckii }\end{array}$ & $\begin{array}{l}\text { Cl. past } \\
\text { euriantm }\end{array}$ & $\begin{array}{l}\text { Mb. } \\
\text { phlei }\end{array}$ & $\begin{array}{l}\text { S. typhi- } \\
\text { murium }\end{array}$ & S. aureus \\
\hline & \multicolumn{9}{|c|}{ 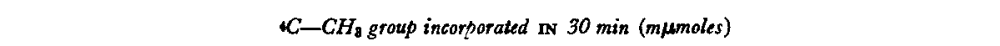 } \\
\hline $\begin{array}{l}\text { (a) Cell extract } \\
\text { from }\end{array}$ & & & & & & & & & \\
\hline E. coli & 0.022 & $<0.001$ & 0.024 & 0.026 & $<0.001$ & 0.006 & 0.042 & 0.008 & 0.016 \\
\hline M. lysodeikticus & $<0.001$ & $<0.001$ & $<0.001$ & 0.001 & 0.001 & 0.026 & 0.004 & 0.001 & 0.002 \\
\hline C. diphtheriae & 0.006 & 0.015 & 0.013 & $<0.001$ & 0.006 & 0.031 & 0.015 & 0.003 & 0.008 \\
\hline L. delbruckii & 0.017 & 0.004 & 0.015 & 0.017 & $<0.001$ & 0.007 & 0.034 & 0.009 & 0.013 \\
\hline Cl. pasteurianum & 0.013 & $<0.001$ & 0.056 & 0.041 & 0.001 & $<0.001$ & 0.027 & 0.032 & 0.049 \\
\hline $\begin{array}{l}\text { (b) Purified } E . \\
\text { coli enzyme }\end{array}$ & 0.200 & $<0.001$ & 0.503 & 0.428 & 0.013 & 0.032 & 0.705 & 0.149 & 0.212 \\
\hline
\end{tabular}

The reaction mixture $(0.25 \mathrm{ml})$ contained : $10 \mu$ moles of Tris buffer, $\mathrm{pH} 8.0,1 \mu$ mole of $\mathrm{MgCl}_{2}$, $2 \mu$ moles of mercaptoethanol, $10 \mathrm{~m} \mu$ moles of ${ }^{14} \mathrm{C}-\mathrm{CH}_{3}$-labeled S-adenosylmethionine $(2.2 \times$ $10^{7} \mathrm{CPM}$ per $\mu$ mole), $150 \mathrm{~m} \mu$ moles of deoxynucleotides as DNA in each case, and $60 \mu \mathrm{g}$ of protein from crude extracts. In the experiments with purified enzyme, $5 \mu \mathrm{g}$ of protein was added, the DNA concentration was reduced to $75 \mathrm{~m} \mu$ moles of deoxynucleotide, and $0.2 \mu \mathrm{g}$ of heated RNAase was included in each reaction mixture. Cell extracts prepared from $M b$. phlei, $S$. typhimurium, and $S$. aureus did not lead to detectable methylation of any DNA preparation and for this reason have not been included in the above table.

From these studies, we have concluded that the over-all base composition of a DNA is not in any obvious way related to its pattern of in vitro methylation. However, several important points can be made. It appears that both the methylated bases, 6-methylaminopurine and 5-methylcytosine, can be formed together in most DNA's, be they viral, bacterial, plant, or animal. Although it has been argued that in vitro enzymatic reactions often lead to artifacts, we can report that work in several laboratories has now established that 5-methylcytosine is indeed a naturally occurring base in some bacterial and phage DNA's $(9,10)$.

The results in Table III show striking differences among $E$. coli strain B, $E$. coli strain $\mathrm{K} 12$, and $\lambda$-bacteriophage. We originally assumed that the in vitro pattern of methylation was a mirror image of the in vivo methylated base content, that is, the production in vitro of a preponderance of 6-methyl- 
aminopurine reflected a DNA in which 5-methylcytosine was the majority base. This has now been demonstrated in the case of $E$. coli B. In vitro, 5methylcytosine is formed almost exclusively. Base composition analysis, however, has revealed that $E$. coli B contains only 6-methylaminopurine in its DNA; moreover, enzymatic studies reveal that, while $E$. coli strains W, K12, $\mathrm{C}$, and 15 contain enzymes capable of catalyzing the formation of both 5methylcytosine and 6-methylaminopurine, extracts of several strains of $E$. coli B can methylate only adenine. In this connection, it is interesting to note that Drs. Oda and Marmur of the Albert Einstein College of Medicine have

T A B L E V

STRAIN SPECIFICITY OF DNA METHYLASE IN $E$. coli

\begin{tabular}{|c|c|c|c|c|c|c|}
\hline \multirow[b]{2}{*}{ Enzyme } & \multicolumn{6}{|c|}{ DNA } \\
\hline & $\begin{array}{l}\text { Methyl-de- } \\
\text { ficent K12 }\end{array}$ & $\mathrm{w}$ & $B$ & K12 & $15 \mathrm{~T}^{-}$ & C \\
\hline & \multicolumn{6}{|c|}{$\mu \mu$ moles $\mathrm{CH}_{8}$ group incorporated } \\
\hline W & 359 & $<2$ & 213 & $<2$ & $<2$ & 21 \\
\hline B & 262 & $<2$ & $<2$ & $<2$ & $<2$ & 4 \\
\hline $\mathrm{K} 12$ & 370 & $<9$ & 200 & $<2$ & $<2$ & 4 \\
\hline $15 \mathrm{~T}^{-}$ & 273 & 119 & 140 & 126 & 111 & 20 \\
\hline C & 362 & $<2$ & 255 & 8 & $<2$ & $<2$ \\
\hline
\end{tabular}

Incubation mixtures were similar to those described previously, except that $300 \mathrm{~m} \mu$ moles of DNA nucleotides and $18 \mu \mathrm{g}$ of enzyme protein were used in each case. The enzyme preparations were all the ASI fraction, representing approximately 100 -fold purification over crude extracts. Incubation was for $90 \mathrm{~min}$.

discovered that certain strains of Bacillus subtilis produce only 5-methylcytosine (11). The fact that a DNA already contains a high concentration of methylated bases does not prevent its further methylation in vitro, as can be seen in the case of wheat germ DNA. This DNA contains probably the greatest number of 5-methylcytosine residues of any DNA so far examined (12). The synthetic deoxynucleotide polymers, dAT, and dGdG, are not methyl acceptors. Drs. Falaschi and Kornberg have recently shown that several other polynucleotides containing deoxyadenylate and deoxycytidylate in various sequences are also inactive (13).

When extracts are made of different kinds of bacteria and these are tested against the DNA's of these bacteria (Table IV), a new property of the methylation reaction emerges, a form of species specificity. Thus, we see that, while each extract methylates the DNA's of some of the other organisms (e.g., $E$. coli extract can methylate the DNA of methyl-deficient $E$. coli, Micrococcus lysodeikticus, Corynebacterium diphtheriae, and Mycobacterium phlei), when homologous extracts and DNA are incubated together, no reaction occurs (e.g., $E$. 
coli with $E$. coli, $M$. lysodeikticus with $M$. lysodeikticus). This homologous restriction can be carried a step further. In Table $V$ are shown results of similar experiments in which the methylating enzymes were extensively purified from several different strains of one species of bacteria, $E$. coli.

All these enzymes were then tested with the purified DNA's of the same strains; all the enzymes were active with the methyl-deficient $E$. coli $\mathrm{K} 12$ DNA. The DNA of $E$. coli B can accept methyl groups from practically all the enzymes from the different strains. The enzyme from strain $15 \mathrm{~T}^{-}$can catalyze

T A B L E V I

DNA METHYLASE AFTER PHAGE INFECTION

\begin{tabular}{lcc}
\hline Phage & Time after infection & DNA Methylase \\
\hline & $\min$ & units $/$ mg protein \\
T2 & 0 & 0.3 \\
& 4 & 27.5 \\
& 15 & 38.8 \\
T3 & 0 & 0.30 \\
& 2 & 0.16 \\
& 6 & $<0.01$ \\
& & $\mu \mu$ moles $/ 30$ min \\
T2 & 15 & 196 \\
T3 & 6 & $<1$ \\
\hline
\end{tabular}

Extracts were prepared by sonication of infected cells at the indicated times and assayed for DNA methylase. In the mixing experiments, the following amounts of extract (in micrograms of protein) were added: T2-infected 13, T3-infected extract 40; the extracts were prepared from cells infected for 15 and 6 min, respectively.

the methylation of all the other DNA's listed here. On the other hand, the enzyme from B shows poor reactivity with the other DNA's, and the DNA of $15 \mathrm{~T}^{-}$is a poor acceptor of methyl groups with any enzyme except its own. In all other cases, homologous restriction occurs; i.e., W with $\mathrm{W}, \mathrm{B}$ with B, $\mathrm{K} 12$ with $\mathrm{K} 12$, and $\mathrm{C}$ with $\mathrm{C}$. The only exception we have found to this rule of homologous restriction thus far has been $15 \mathrm{~T}^{-}$. It is interesting that the one exception to homologous restriction does occur in strain $15 \mathrm{~T}^{-}$, since it was in this very strain, grown under conditions which led to unbalanced growth, that Dunn and Smith first discovered 6-methylaminopurine.

Using the purified enzyme of $E$. coli W, we have methylated, in vitro, various DNA's in order to obtain some clues as to the possible function of the methylated bases. Some of the systems we have examined for the effect of enzymatic methylation of DNA may now be summarized. When transforming DNA of 
Pneumococcus or Bacillus subtilis is methylated in vitro and then tested, no significant effect could be found on the integration of genetic markers. In vitro, no effect of methyl groups on the template activity of DNA, for either DNA or RNA synthesis with purified enzymes, could be detected (7). Finally,

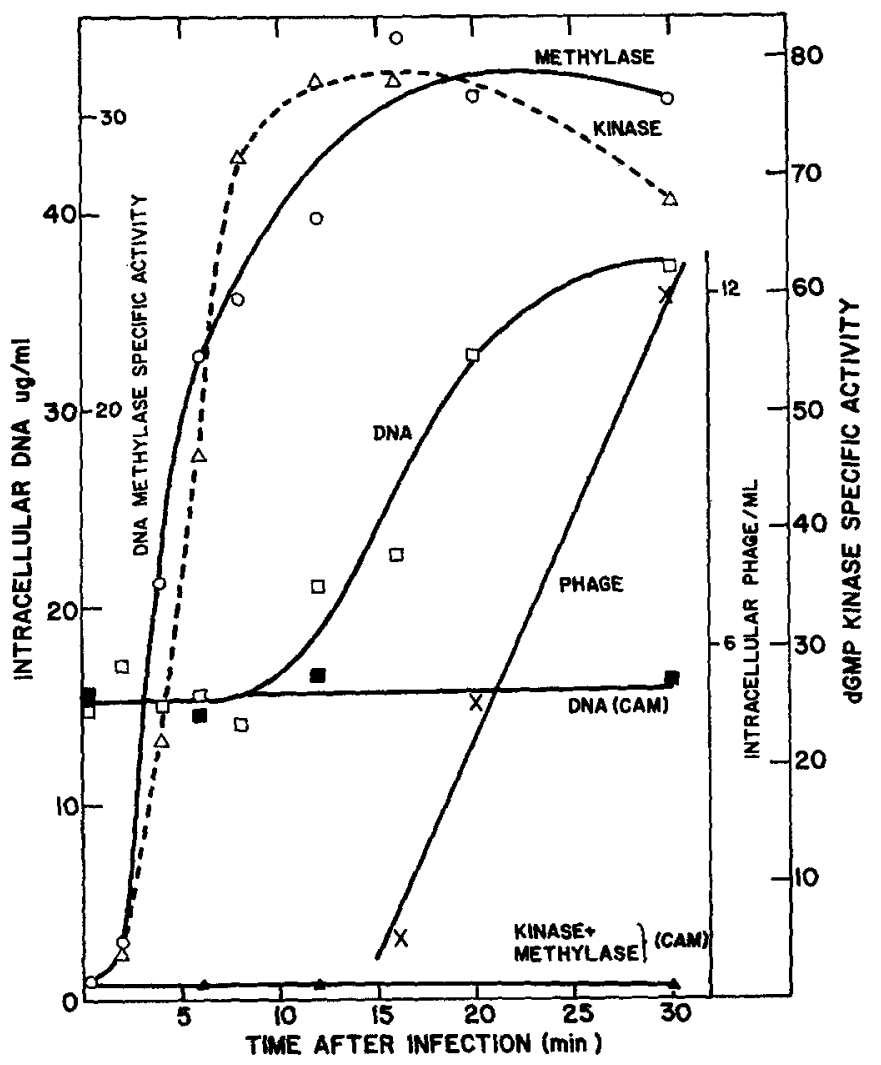

FIGURE 4. Enzyme, DNA, and phage synthesis in T2-infected bacteria. Bacteria were grown at $37^{\circ}$ to a density of $6 \times 10^{8}$ per $\mathrm{ml}$ and infected with $\mathrm{T} 2$ at a multiplicity of 5 phage per bacterium. At the indicated times, samples were withdrawn for the indicated measurements. Intracellular phage were measured after premature lysis in cyanide with T6. When protein synthesis was to be inhibited, chloramphenicol (50 $\mu \mathrm{g}$ per $\mathrm{ml}$ final concentration) was added at 0 time. The open symbols denote a normal infection, while the closed symbols represent experiments in which chloramphenicol was added (CAM).

methylated DNA did not in any way show any marked resistance or susceptibility to various deoxyribonucleases. While the results of experiments such as these are disappointing, we decided to study methylation of DNA in bacteriophage, since it has been known for a long time that T2 DNA contains 6-methylaminopurine, and it was of interest to determine what enzymes were responsible for its formation. We also hoped that in the bacteriophage system 
with its numerous well studied biochemical and biological aspects we might be able to discover the function of the methylated bases. When DNA methylase activity was measured in extracts of phage-infected $E$. coli $\mathrm{B}$, two types of response were found (Table VI). In the case of $\mathrm{T} 2$, there was a very marked increase in the specific activity of the enzyme; this increase was already evident a few minutes after infection. In the case of T3, however, we see that the activity decreased, and by $6 \mathrm{~min}$, the reaction was virtually abolished (14). When extracts of T2-infected cells were mixed with extracts of T3-infected cells, it became evident that there was a potent inhibitor present in T3infected cells which was preventing us from assaying the DNA methylase.

The changes in DNA methylase activity in $E$. coli after infection with various phages are summarized in Fig. 3. The largest increase in enzyme activity occurs with T2; T4 and T1 show smaller rises. Infection with T7 or $\lambda$ (whether by induction or by external infection) produces very little change. T5 and T6 show slight decreases in activity and as we mentioned previously, T3 provokes a very rapid and marked loss of activity. It now appears that the increase in the activity of DNA methylase after T2 infection is due to the appearance of a new phage-directed enzyme similar to the other well known so-called "early enzymes," which appear after T-even infection (15). It seems that T6 does not show this effect; in all other cases studied, T2, T4, and T6 behave fairly similarly in this regard.

Some of the results of our studies of this phenomenon in T2-infected cells are shown in Fig. 4. In the case of DNA methylase, we see that the activity can be determined easily within $2 \mathrm{~min}$, rises steadily for about $12 \mathrm{~min}$, and then levels off. Also shown is the activity of deoxynucleotide kinase, a well characterized phage-induced early enzyme (16). We see that the kinetics of both these enzymes are quite similar. Both enzymes reach their peak activity at a time when phage DNA synthesis is commencing and before infectious phage particles can be recovered from inside the infected cells. If chloramphenicol, an inhibitor of protein synthesis, is added at the time of infection, neither enzyme activity appears, and, of course, neither phage DNA nor phage is made. These results suggest that the activity of the DNA methylase found after T2 infection is due to a phage-directed, new enzyme. This enzyme has been extensively purified, and some of its properties may be summarized as follows.

The specific activity of this enzyme at a comparable stage of purification is some 300 -fold greater than that from uninfected $E$. coli W; i.e., 30,000 units per mg protein. These units are expressed in terms of millimicromoles of methyl group incorporated in $30 \mathrm{~min}$. Only 6-methylaminopurine is found in the methylation products made in a large variety of DNA's with this T2induced enzyme. It should be pointed out, however, that this enzyme has been purified from T2-infected $E$. coli B. As may be recalled, uninfected $E$. coli B 
produces only 6-methylaminopurine. We have, therefore, purified T2-induced methylase from phage-infected $E$. coli $\mathrm{W}$ and $\mathrm{K} 12$ and have shown that in these cases also only 6-methylaminopurine is formed. In contrast to the enzymes from $E$. coli $\mathrm{W}$, or from uninfected $E$. coli $\mathrm{B}$, the $\mathrm{T} 2$ enzyme shows activity, although somewhat reduced, with heat-denatured DNA. We have been unable to determine whether homologous restriction occurs when the purified enzyme is incubated with DNA isolated from mature T2 phage particles, since either the DNA preparation or the enzyme or both contain

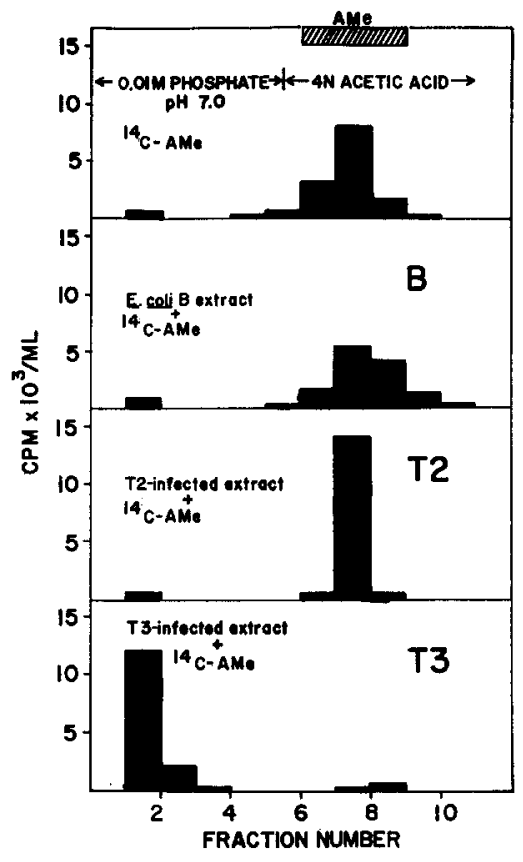

Figure 5. Chromatography of reaction mixtures on XE-64 ion exchange resin. Incubations and chromatography were performed as described previously with the following amounts of cell extract (in micrograms of protein): $E$. coli B 53, T2-infected 66 , and T3-infected 13.2. The cross-hatched area at the top of the figure represents the ultraviolet light-absorbing material of unlabeled authentic S-adenosylmethionine abbreviated AMe) added to the column as a marker.

unknown factors which complicate the study of the specificity of the enzyme. The yield of methylation with certain DNA's seems to be dependent on the stage of purification and also on the amount of enzyme used. As the enzyme is purified more and more extensively, less and less reaction occurs with T2 DNA. However, we have discovered that wetting agents, such as the Tweens, markedly stimulate the activity of the purified enzyme. This is not the case with the enzyme from $E$. coli $\mathrm{W}$ or from uninfected $E$. coli $\mathrm{B}$. Falaschi and Kornberg have recently shown that the lipopolysaccharides are potent inhibitors of the T2-induced DNA methylase (13). We have confirmed their observation and have shown that Tween can overcome this inhibition. It becomes imperative, therefore, when working with the phage enzyme that utmost purity of both the DNA substrate and the methylase be obtained. Nevertheless, in the properties discussed here and from other studies, we 
believe that the activity found in T2-infected cells is a newly synthesized, phage-directed protein.

Amber mutants of T2 and T4, that is, mutants which cannot replicate in $E$. coli $\mathrm{B}$, but can grow in other strains of $E$. coli, induce in $E$. coli $\mathrm{B}$ levels of enzyme activity which are several fold higher than those found in extracts of

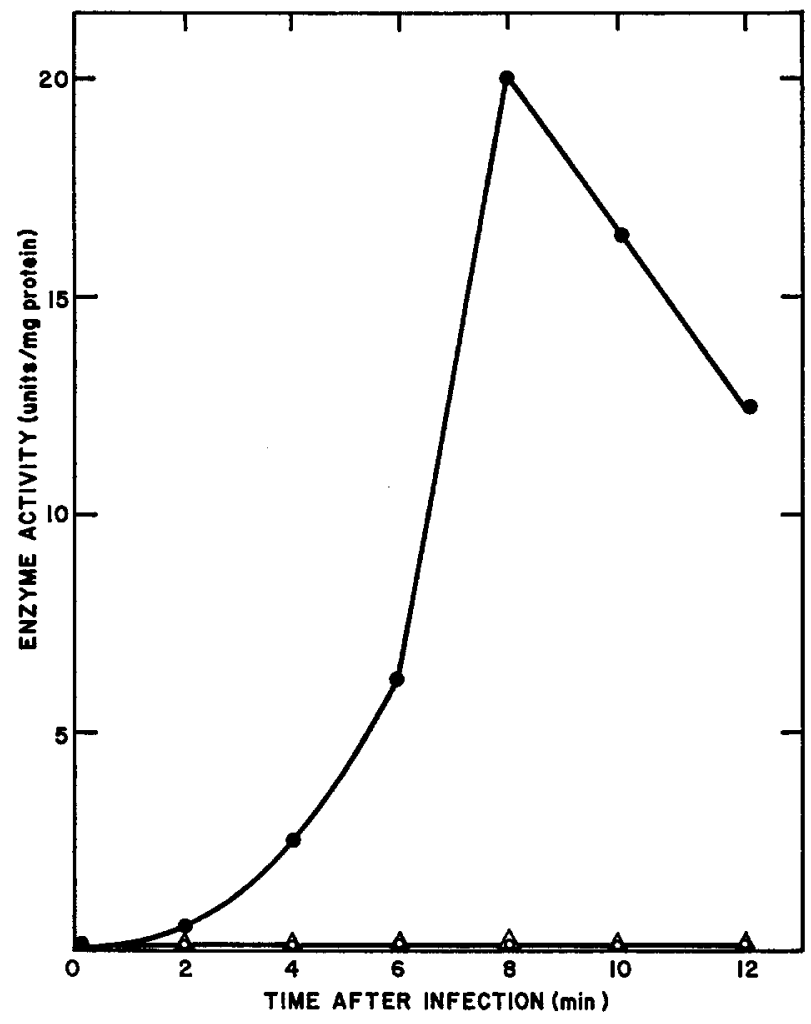

FIGURE 6. Rate of formation of S-adenosylmethionine cleaving activity after infection of $E$. coli B with T3 and T7. E. coli B was infected with phage T3 (solid circles) and T7 (open circles) and cell-free extracts were prepared at various times after infection and assayed for enzyme activity. Infection of $E$. coli B with T3 was also carried out in the presence of $50 \mu \mathrm{g}$ of chloramphenicol per $\mathrm{ml}$ (open triangles). The antibiotic was added at the time of infection.

bacteria infected with wild type of bacteriophage. A survey of several such amber mutants in different genes of the phage chromosome has not as yet revealed any mutant defective in the production of DNA methylase.

The inhibitor of methylation found in extracts of T3-infected cells was shown not to be a nuclease, and we decided, therefore, to examine the fate of the methyl donor, S-adenosylmethionine. The effects of incubating Sadenosylmethionine with extracts of various cells are shown in Fig. 5. The 
reaction mixtures were incubated and then chromatographed on columns of $\mathrm{XE}-64$ cation exchange resin. By virtue of the strong positive charge of the sulfonium group in S-adenosylmethionine, this compound sticks very tightly to the column and can only be eluted with concentrated acid. When Sadenosylmethionine is incubated with extracts of uninfected $B$ or T2-infected $\mathrm{B}$, we see that it has elution profiles similar to those of the control. However, in an incubation mixture containing extracts of T3-infected cells, more than

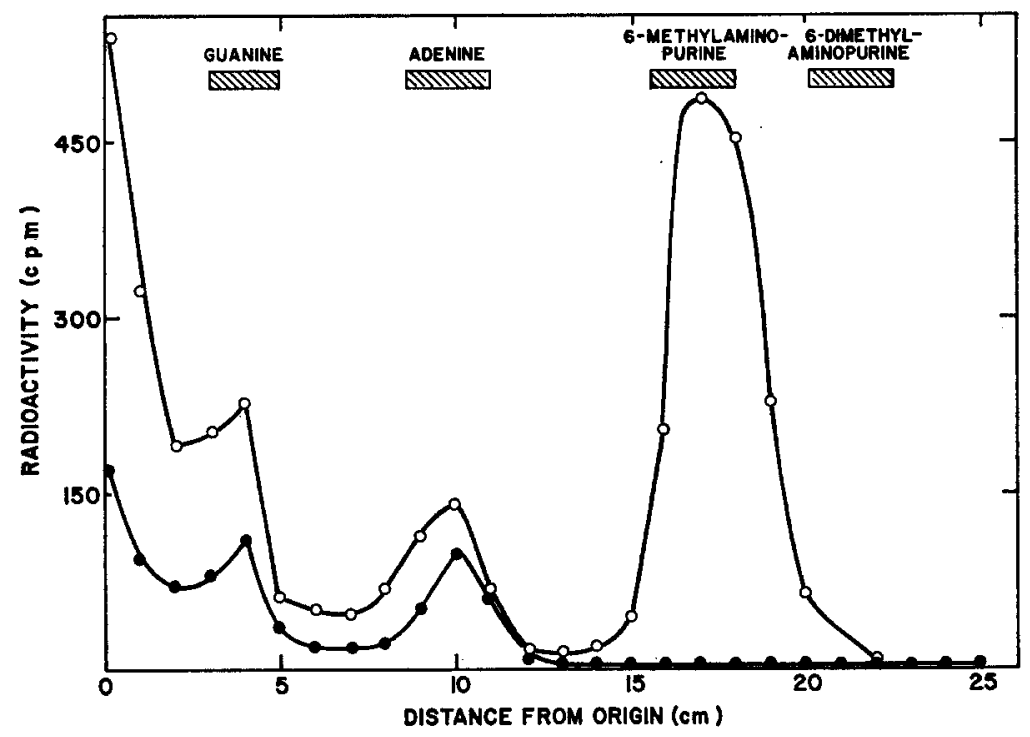

FIGURE 7. The incorporation of radioactivity into DNA isolated from phages T3 and $\mathrm{T} 7$ grown in the presence of ${ }^{14} \mathrm{C}$-methyl-labeled methionine. Paper chromatography of $1 \mathrm{~N} \mathrm{HCl}$ hydrolysates of DNA isolated from bacteriophage T3 (solid circles), and bacteriophage $\mathrm{T} 7$ (open circles) grown in the presence of ${ }^{14} \mathrm{C}$-methyl-labeled methionine $\left(3.1 \times 10^{6} \mathrm{CPM}\right.$ per $\left.\mu \mathrm{mole}\right)$. The lines labeled with the various bases denote the position of authentic markers located under ultraviolet light.

$90 \%$ of the radioactivity is eluted from the column with dilute neutral buffer (14). Analysis of this breakdown product has shown it to be thiomethyladenosine. Further work has established that S-adenosylmethionine is actively cleaved by an enzyme present in T3-infected bacteria to yield thiomethyladenosine and homoserine. This enzyme has now been extensively purified and its properties studied. The activity of this enzyme, even in crude extracts, is several orders of magnitude greater than that of even the T2-induced methylase and, therefore, in T3-infected cells no DNA methylase, or, for that matter, RNA methylase, can be detected, since the methyl group donor is very rapidly destroyed.

The kinetics of appearance of this enzyme are shown in Fig. 6. The enzyme 


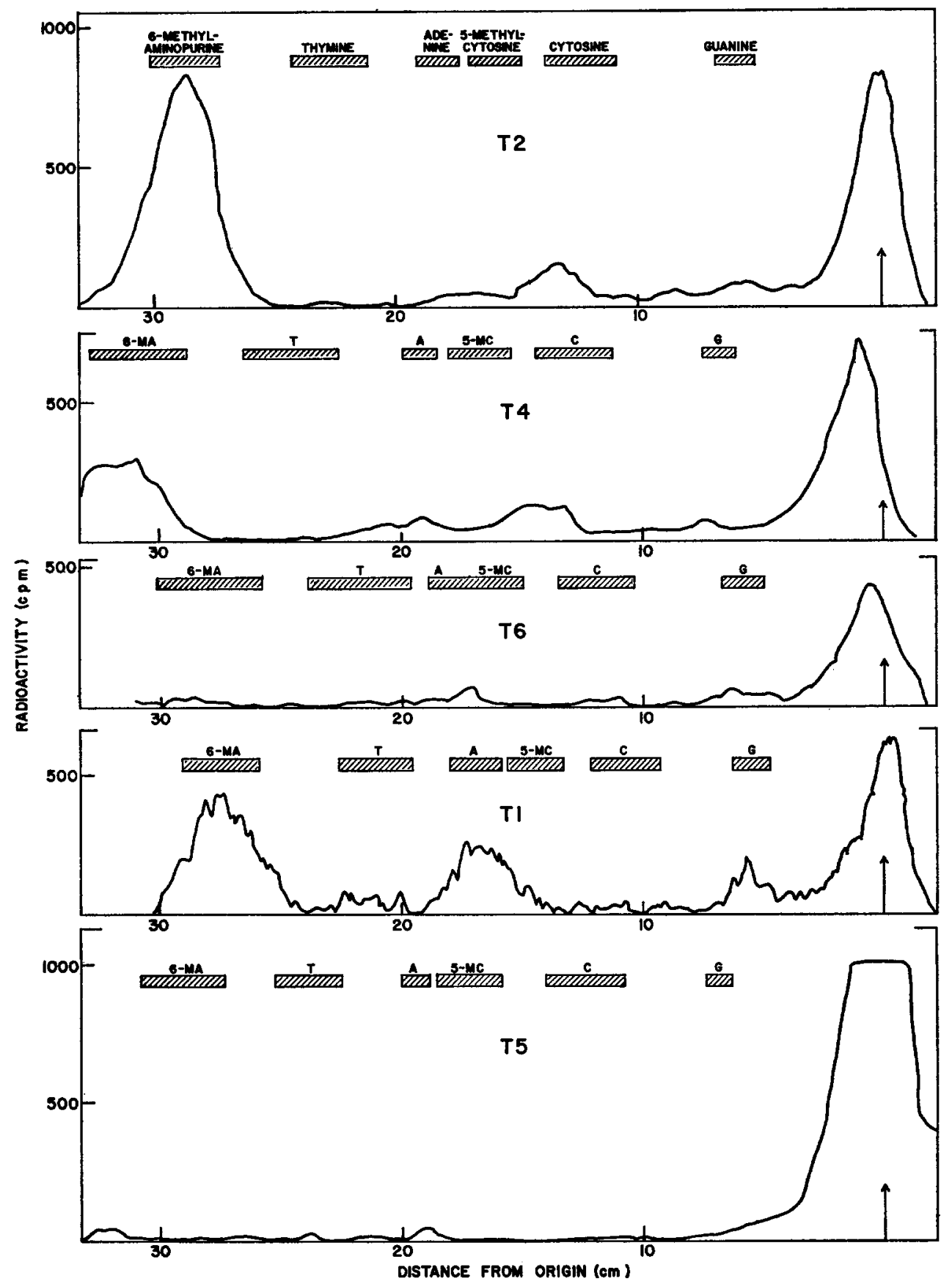

FIGURE 8. Radioactive scans of paper chromatograms of formic acid hydrolysates isolated from bacteriophages grown in the presence of ${ }^{14} \mathrm{C}$-methyl-labeled methionine. Elution and rehydrolysis of the radioactive material remaining at the origin did not affect its migration. In the case of $T 1$, adenine and uracil were not added to the growth medium. In the case of $\mathrm{T} 2$ and $\mathrm{T} 4$, the small amount of radioactivity migrating between cytosine and 5-methylcytosine is believed to be a breakdown product of 6-methylaminopurine. 
activity cannot be detected with certainty in uninfected cells, but it is readily measured by $2 \mathrm{~min}$ after infection. The activity rises rapidly and reaches a peak at about 8 min after infection; thereafter, it declines. These cells, infected with T3, lyse at about $13 \mathrm{~min}$. When chloramphenicol was added simultaneously with $\mathrm{T} 3$, there was no detectable activity. We have also shown here the results of T7 infection; T7 is a phage very closely related to T3, chemically, genetically, morphologically, and radiobiologically. No detectable S-adenosylmethionine-cleaving activity is formed after T7 infection. Thus, it seems that

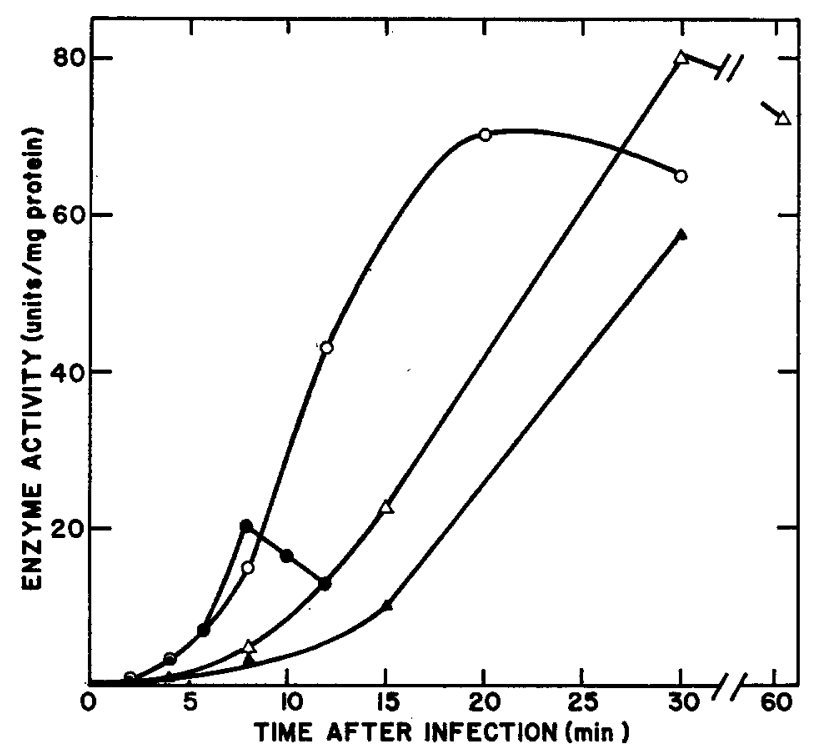

Figure 9. S-Adenosylmethionine cleavage activity after infection with ultraviolet light-inactivated T3. The appearance of enzyme activity following infection of $E$. coli B with: (a) normal phage T3, MOI $=5$ (solid circles); (b) ultraviolet light-inactivated T3 at $10^{-2}$ survival, MOI $=2$ (open circles); $10^{-6}$ survival, MOI $=5$ (open triangles) and at $10^{-6}$ survival, MOI $=1$ (solid triangles).

this is an early enzyme peculiar to T3 infection, and no other phages thus far studied lead to its production (17).

It is easy to predict, therefore, that T3 DNA should contain no methylated bases since the progeny DNA is synthesized in an environment where methylation is impossible. This is borne out in the results shown in Fig. 7 which represent radioactive scans of chromatograms of hydrolysates of T3 and T7 DNA extracted from phages grown in the presence of methyl-labeled methionine. Under the conditions of growth used here and with the particular mutant of $E$. coli B used, radioactivity from the methyl carbon is incorporated into the ring positions of the purine bases. However, we see that in this solvent system 6-methylaminopurine is well separated from the other purines. The 
DNA of T7 contains 6-methylaminopurine, while T3, as far as we can tell, is devoid of this base. The chromatograms shown here are those of a mild hydrochloric acid hydrolysate in which only the purine bases are released. Formic acid hydrolysates in which the pyrimidine bases are also released give similar results and also indicate that neither T3 nor T7 contains 5-methylcytosine. Radioactive scans of chromatograms of hydrolysates of the DNA of

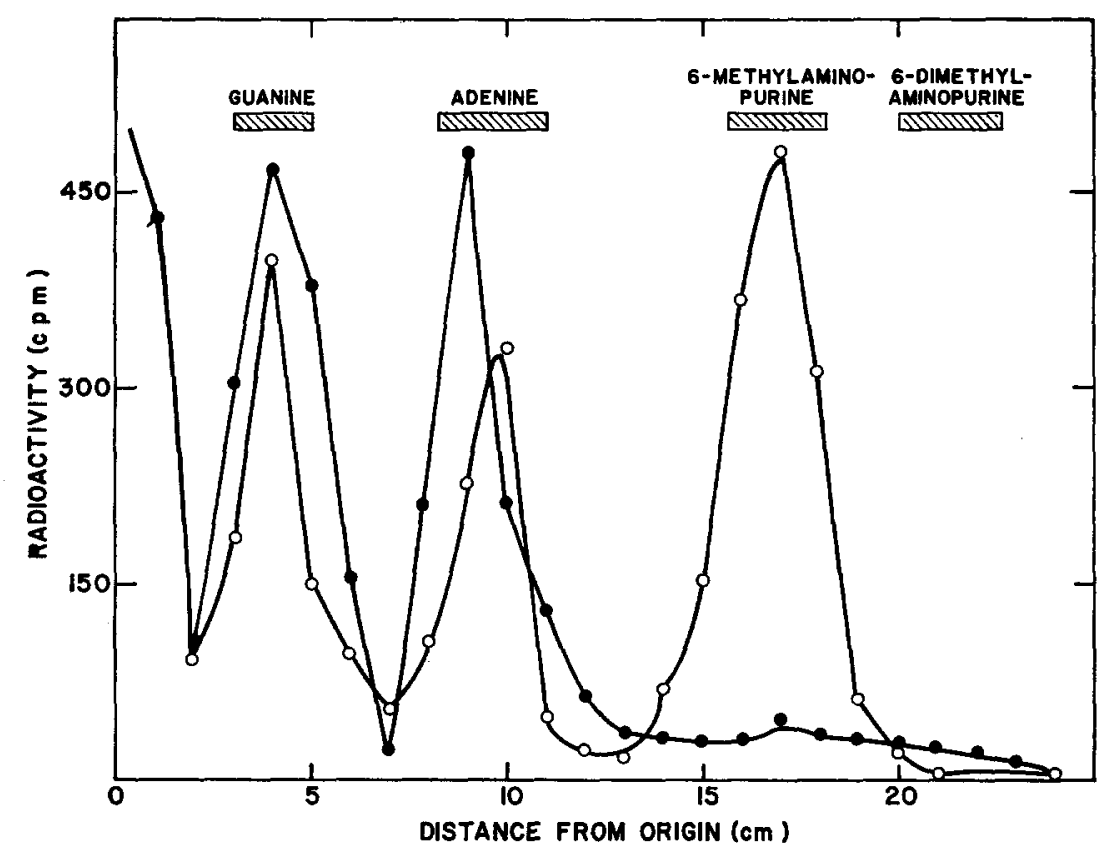

FIGURE 10. Incorporation of radioactivity into T2 DNA isolated from T2 phage grown in the presence of ${ }^{14} \mathrm{C}$-methyl-labeled methionine. Paper chromatography of $1.0 \mathrm{~N} \mathrm{HCl}$ hydrolysates of DNA isolated from bacteriophage T2 (open circles), and T2 grown in bacteria infected with ultraviolet light-inactivated T3 (solid circles).

other phages, again grown in the presence of methyl-labeled methionine, are shown in Fig. 8.

It is clear that $\mathrm{T} 1, \mathrm{~T} 4$, and $\mathrm{T} 2$ contain 6-methylaminopurine, but $\mathrm{T} 6$ and T5 do not contain this base. As was described, T1, T2, and T4 were the very phages which brought about an increase in the activity of DNA methylase, while $\mathrm{T} 5$ and $\mathrm{T} 6$ did not. It is also interesting that $\mathrm{T} 6$ does not contain methylated bases in contrast to T2 and to T4, and we have some evidence that the glucosylation pattern of these phages plays a role in their methylation.

In order to make use of the unique properties of T3, it was first necessary to establish conditions whereby infection could be carried out with this phage so that the enzyme which can cleave S-adenosylmethionine would be produced, but $\mathrm{T} 3$ replication itself would not occur. 
The effects of infecting $E$. coli B with ultraviolet light-inactivated T3 are shown in Fig. 9. At a survival of $10^{-2}$, we see that the enzyme continues to increase long after normal infection leads to lysis of the cells (which occurs at about 12 or $13 \mathrm{~min}$ ) and levels of enzyme three- to four-fold higher are attained. As the phages are inactivated to an even lower survival, there is an initial lag, but the final rates of production of enzyme seem to be proportional to the multiplicity of infection. We have found that under certain conditions of infection with ultraviolet light-inactivated phages, lysis of the cell does not

T A B L E V I I

RECOMBINATION IN THE ABSENCE OF METHYLATION

\begin{tabular}{lccc}
\hline & Normal cross & $\begin{array}{c}\text { Cross in UV T3- } \\
\text { infected cells }\end{array}$ & $\begin{array}{c}\text { Cross in UVT7- } \\
\text { infected cells }\end{array}$ \\
\hline Plaques on B & $1.8 \times 10^{10}$ & $5.5 \times 10^{10}$ & $\begin{array}{l}1.2 \times 10^{10} \\
\text { Plaques on KB }\end{array}$ \\
Recombination, per cent & $0.1 \times 10^{8}$ & $3.2 \times 10^{8}$ & $\begin{array}{c}7.4 \times 10^{8} \\
0.61\end{array}$ \\
\hline
\end{tabular}

Crosses were carried out with T4 rIIB114 and T4 rIIB287 in $E$. coli B. E. coli $\mathrm{KB}$ was used as an indicator strain to score wild-type recombinants (all bacterial strains and phage stocks were kindly supplied by Dr. Benzer). E. coli $\mathrm{B}$ was grown in casamino acids medium to a density of $3 \times 10^{8}$ bacteria per $\mathrm{ml}$. The culture was divided into three portions; one was infected with ultraviolet light-inactivated $\mathrm{T} 3$ (MOI $=5$ ), one with ultraviolet lightinactivated T7 (MOI $=5$ ), and one remained untreated. Ten min later each culture was infected with equal amounts of T4 rIIBI 14 and T4 rIIB287 at an MOI $=3$. The infection was allowed to proceed for $20 \mathrm{~min}$ at which time the infected cells were lysed with chloroform. Appropriate dilutions of the lysates were made and plated on both $E$. coli $\mathrm{B}$ and on $E$. coli $\mathrm{KB}$ in triplicate. The results given above are corrected to plaque-forming units in the original lysates.

occur for at least $2 \mathrm{hr}$, and while phage DNA is not synthesized, host DNA and RNA synthesis continue, although at slightly lower rates. We have shown that the host DNA and RNA synthesized after infection of $E$. coli B with ultraviolet light-inactivated T3 are unmethylated (17).

To make use of this system, we have adopted the method outlined in Scheme 2.

Scheme II. Method for making phages containing unmethylated DNA.

Step 1. T3(UV) $+E$. coli B $\rightarrow E$. coli B containing SAM'ase

Step 2. $\mathrm{T} 2+E$. coli $\mathrm{B}$ containing SAM'ase $\rightarrow \mathrm{T} 2$ progeny without $\mathrm{CH}_{3}$ groups $\left(\mathrm{T} 2 \mathrm{M}^{-}\right)$

We first infect $E$. coli B with T3 inactivated to a survival of approximately $10^{-4}$. As a result, we now have infected cells producing the S-adenosylmethionine-cleaving enzyme which, for convenience, we will call Sam'ase. These infected cells are allowed to incubate for 10 to $20 \mathrm{~min}$ to allow the intracellular concentration of Sam'ase to build up. T2 is then added to these 
Sam'ase-containing cells, and aeration is continued until lysis occurs. The lysate contains only $\mathrm{T} 2$; this has been established by electron microscopy, plaque morphology, and host range. The T2 grown in this way should contain no methylated bases in their DNA, and we have chosen to call them $\mathrm{T}_{2} \mathrm{M}^{-}$. When phages are prepared in this manner in the presence of ${ }^{14} \mathrm{C}$ $\mathrm{CH}_{3}$-labeled methionine, base composition analysis gives the results shown in Fig. 10. In contrast to normal $\mathrm{T} 2$, the $\mathrm{T} 2 \mathrm{M}^{-}$contains virtually no 6methylaminopurine. In a similar way, unmethylated phages can also be prepared with $\mathrm{T} 4$. The properties of these unmethylated phages may be briefly summarized as follows.

\begin{tabular}{|c|c|c|c|}
\hline \multirow{2}{*}{$\begin{array}{l}\text { Purified enzyme } \\
\text { isolated from strain }\end{array}$} & \multicolumn{3}{|c|}{ DNA } \\
\hline & Mb. phlei & $\lambda-K$ & $\lambda-\mathbf{C}$ \\
\hline & \multicolumn{3}{|c|}{$\mu \mu$ moles $\mathrm{CH}_{\mathrm{s}}$ groups $/ 120 \mathrm{~min}$} \\
\hline W & 627 & 52 & 4 \\
\hline B & 354 & 23 & $<1$ \\
\hline $\mathrm{K} 12$ & 518 & 39 & 3 \\
\hline C & 495 & 27 & 11 \\
\hline
\end{tabular}

\footnotetext{
All incubations were carried out with 50 m $\mu$ moles of DNA and $18 \mu \mathrm{g}$ of enzyme protein for $120 \mathrm{~min}$ at $38^{\circ} \mathrm{C}$. The $\lambda(\mathrm{K} 12)$ was a spontaneous mutant of $\lambda$ which was characterized by the ability to form clear plaques on $E$. coli $\mathrm{K} 12$, but no plaques on $\mathrm{K} 12(\lambda)$.
}

They grow normally in several dozen strains of $E$. coli which were tested; i.e., their titers were comparable within experimental error. When these phages were used to produce infected cultures, early enzyme synthesis proceeded normally. In the electron microscope, they appear to be identical with normal phage. The phages with unmethylated DNA show normal ultraviolet light sensitivity either as free phage or as infected complexes in Luria-Latarjet type of experiments. DNA extracted from these phages acts normally as a template for in vitro RNA synthesis (18) and RNA chain initiation (19) with purified RNA polymerase (1).

We have also studied genetic recombination of unmethylated phages by doing standard two factor crosses in cells previously infected with ultraviolet light-inactivated T3. The results of a cross involving rII mutants (20) are shown in Table VII. As controls, identical crosses were performed in uninfected B and in B previously infected with ultraviolet light-inactivated T7. The number of plaques on $B$ gives the total progeny of the cross; the plaques on KB give only the wild-type recombinants. As can be seen, the percentage of wild-type recombinants is identical in each case.

One other system in which we have studied the effects of methylation is 
host-induced modification (20). When phage $\lambda$ infects $E$. coli strain K12, the progeny, which are called $\lambda \cdot \mathrm{K}$, can plate equally well on $E$. coli $\mathrm{C}$ and $E$. coli $\mathrm{K} 12$. On the other hand, when $\lambda$ is grown on $\mathrm{E}$. coli strain $\mathrm{G}$, the progeny $\lambda \cdot \mathrm{C}$ plates normally on $E$. coli $\mathrm{C}$ but very poorly on $E$. coli $\mathrm{K} 12$ (efficiency of plating is approximately $10^{-4}$ ). This property of modification, or restriction, is not genetic since it cannot be transmitted to progeny, but it appears to be a host-specific modification of the phage DNA as it passes through each cycle of growth (21). It is very tempting to assign to DNA methylation a role in this phenomenon, which, incidentally, is not limited to $\lambda$, but appears to be also true of other phages (22) and also bacterial DNA (23).

T A B L E I X

HOST SPECIFICITY OF METHYL-DEFICIENT $\lambda$

\begin{tabular}{lcccc}
\hline \multirow{2}{*}{ Phage } & \multicolumn{4}{c}{ Titer on E. coli strain } \\
\cline { 2 - 5 } & $\mathrm{B}$ & $\mathrm{K} 12$ & $\mathrm{~K} 12(\mathrm{P} 1)$ & $\mathrm{C}$ \\
\hline$\lambda-\mathrm{B}$ & $2.4 \times 10^{9}$ & $3.1 \times 10^{8}$ & $<10^{3}$ & $3.2 \times 10^{9}$ \\
$\lambda-\mathrm{B}(\mathrm{T} 3)$ & $2.0 \times 10^{9}$ & $4.5 \times 10^{6}$ & $<10^{3}$ & $3.5 \times 10^{9}$ \\
\hline
\end{tabular}

Methyl-deficient $\lambda$ was prepared by induction of $E$. coli B208 $\left(\lambda_{\mathrm{CI} 857}^{\mathrm{ind}-}\right)$ (both $B 208 \lambda^{\text {sens }}$ and $\lambda_{\text {CI857 }}^{\text {ind-- }}$ were kindly supplied by Dr. Yarmolinsky) with high temperature $\left(44^{\circ} \mathrm{C}\right)$. The lysogenic strain was grown at $34^{\circ} \mathrm{C}$ in $\mathrm{M} 9$ medium supplemented with yeast extract $(5 \mathrm{mg} / \mathrm{ml})$ to a cell density of $2 \times 10^{8}$ bacteria per $\mathrm{ml}$, and then transferred to $44^{\circ} \mathrm{C}$ for $7 \mathrm{~min}$. Ultraviolet light-inactivated $\mathrm{T} 3$ was then added at a $\mathrm{MOI}=10$ and incubation at $44^{\circ} \mathrm{C}$ was continued for $23 \mathrm{~min}$. The cultures were then transferred to $34^{\circ} \mathrm{C}$ and aerated with a mixture of oxygen and air (1:1) until lysis occurred (45 min). The phages were then plated on the strains indicated.

When DNA is isolated from $\lambda \cdot \mathrm{K}$ and $\lambda \cdot \mathrm{C}$ and incubated with purified enzymes from various strains of $E$. coli, we see that $\lambda \cdot \mathrm{C}$ is not as good an acceptor of methyl groups as $\lambda \cdot K$ (Table VIII). This can be taken to mean that in vivo, $\lambda \cdot \mathrm{C}$ may be more highly methylated than $\lambda \cdot \mathrm{K}$, as we have discussed previously. These experiments were done several years ago, and in the interim there have been conflicting reports in various laboratories on the role of methylated bases in the phenomenon of host-induced modification $(10,24)$. In brief, it has been postulated that, on passage through $E$. coli $\mathrm{C}$, the $\lambda$-DNA is methylated in such a manner that the enzymes in $\mathrm{K}$ recognize this pattern and degrade this DNA when it enters the cell. To further test this hypothesis, we have performed the following experiments. In a manner quite similar to that we described earlier, $\lambda$ has been induced in $E$. coli $\mathrm{B}(\lambda)$ previously infected with ultraviolet light-inactivated T3. The phage so produced has been shown by chemical analysis (using methyl-labeled methionine of high specific activity) to be devoid of methylated bases. The results in Table IX illustrate the plating efficiencies of normal $\lambda \cdot B$ and $\lambda \cdot B$ devoid of methyl groups on 
various strains of coli, each of which has its own restriction and modification pattern. There is no significant difference between these two phages when plated on the four strains of $E$. coli used here. While these results may at first glance be interpreted to mean that methylation plays no role in this phenomenon, it should be pointed out that similar experiments with $T 1(25,26)$ grown in T3-infected K12 indicate that methylated bases do, in fact, influence the host-controlled modification of this phage. In our laboratory, however, we have been unable to use the $\mathrm{K} 12$ system of modification since infection of this strain with T3 does not lead to the production of Sam'ase until 40 to $60 \mathrm{~min}$ after infection.

In summary then, even though we know a great deal about the enzymology of the methylation reaction, and there appears to be a strong correlation between the in vitro and in vivo pattern of methylation, studies in which DNA is either supermethylated in vitro, or becomes totally unmethylated in vivo, have not yielded any insight as to what the possible function of methylated bases may be.

This work was supported by grants from the National Institutes of Health, the National Science Foundation, and the New York City Public Health Research Council.

Mr. Gefter is a Predoctoral Trainee of the National Institutes of Health.

Dr. Hausmann was a Postdoctoral Fellow of The Rockefeller Foundation.

\section{REFERENCES}

1. Wyatt, G. R., Recognition and estimation of 5-methylcytosine in nucleic acids, Biochem. J., 1951, 48, 581.

2. Dunn, D. B., and Smith, J. D., The occurrence of 6-methylaminopurine in deoxyribonucleic acid, Biochem. J., 1958, 68, 627.

3. Kornberg, A., Zimmerman, S. B., Kornberg, S. R., and Josse, J., Enzymatic synthesis of deoxyribonucleic acid. VI. Influence of bacteriophage T2 on the synthetic pathway in host cells, Proc. Nat. Acad. Sc., 1958, 44, 641.

4. FLEISSNER, E., and Borek, E., A new enzyme of ribonucleic acid synthesis: RNA methylase, Proc. Nat. Acad. Sc., 1962, 48, 1199.

5. Gold, M., Hurwitz, J., and ANDERs, M., The enzymatic methylation of RNA and DNA. I, Biochem. and Biophysic. Research Commun., 1963, 11, 107.

6. Gold, M., and Hurwitz, J., The enzymatic methylation of RNA and DNA. V. Purification and properties of the DNA methylating activity of Escherichia coli, J. Biol. Chem., 1964, 239, 3858.

7. Gold, M., and Hurwitz, J., The enzymatic methylation of RNA and DNA. VI. Further studies on the properties of the DNA methylation reaction, $J$. Biol. Chem., 1964, 239, 3866.

8. Kornberg, A., Enzymatic synthesis of deoxyribonucleic acid, Harvey Lectures, $1957-58,53,83$.

9. Doskocil, J., and Sormova, Z., The occurrence of 5-methylcytosine in bacterial deoxyribonucleic acids, Biochim. et Biophysica Acta, 1965, 95, 515. 
10. Ledinko, N., Occurrence of 5-methyldeoxycytidylate in the DNA of phage lambda, J. Mol. Biol., 1964, 9, 834.

11. OdA, K., and Marmur, J., Purification and properties of deoxyribonucleic acid methylase from Bacillus subtilis, Biochemistry, 1966, 5, 761.

12. Chargaff, E., in The Nucleic Acids, (E. Chargaff and J. N. Davidson, editors), New York, Academic Press Inc., 1955, 1, 358.

13. Falaschi, A., and Kornberg, A., A lipopolysaccharide inhibitor for a DNA methyl transferase, Proc. Nat. Acad. Sc., 1965, 54, 1713.

14. Gold, M., Hausmann, R., Maitra, U., and Hurwitz, J., The enzymatic methylation of RNA and DNA. VIII. Effects of bacteriophage infection on the activity of the methylating enzymes, Proc. Nat. Acad. Sc., 1964, 52, 292.

15. Hausmann, R., and Gold, M., The enzymatic methylation of ribonucleic acid and deoxyribonucleic acid. IX. DNA methylase in bacteriophage-infected Escherichia coli, J. Biol. Chem., 1966, 241, 1985.

16. Bello, L. J., Van Bibber, M. J., and Bessmann, M. J., The enzymology of virus-infected bacteria, J. Biol. Chem., 1961, 236, 1467.

17. Gefter, M., Hausmann, R., Gold, M., and Hurwitz, J., The enzymatic methylation of ribonucleic acid and deoxyribonucleic acid. X. Bacteriophage T3induced S-adenosylmethionine cleavage, J. Biol. Chem., 1966, 241, 1995.

18. Maitra, U., and Hurwitz, J., Nucleoside triphosphate termini in RNA polymerase products, Proc. Nat. Acad. Sc., 1965, 54, 815.

19. Novogrodsky, A., Gefter, M., Maitra, U., Gold, M., and Hurwitz, J., The role of DNA in RNA synthesis. X. The influence of 6-methylaminopurine on nucleic acid synthesis in vitro, J. Biol. Chem., 1966, 241, 1977.

20. Bertani, G., and Weigle, J. J., Host-controlled variation in bacterial viruses, J. Bact., 1953, 65, 113.

21. Arber, W., and Dussoix, D., Host specificity of DNA produced by Escherichia coli, J. Mol. Biol., 1962, 5, 18.

22. LuRia, S. E., and Human, M. L., A non-hereditary, host-induced variation of bacterial viruses, J. Bact., 1952, 64, 557.

23. Arber, W., and Morse, M. L., Host specificity of DNA produced by Escherichia coli. VI. Effects on bacterial conjugation, Genetics, 1965, 51, 137.

24. Arber, W., The role of methionine in the production of host specificity, J. Mol. Biol., 1965, 11, 247.

25. Klein, A., and SAURBIER, W., Role of methylation in host-controlled modification of phage T1, Biochem. and Biophysic. Research Commun., 1965, 18, 440.

26. KLEIN, A., Mechanismen der wirtskontrollierten Modifikation des Phagen T1, Z. Vererbungslehre, 1965, 96, 246.

\section{Discussion}

Dr. Jonathan P. Kabat: Dr. Gold, I didn't get one thing straight. Did you say that the DNA from $E$. coli B contained 6-methylaminopurine or 5-methylcytosine primarily? 
Dr. Gold: When E. coli B DNA is methylated in vitro, the product made with a heterologous enzyme is 5-methylcytosine, but when you extract the DNA from a normal cell and just examine what it contains, it contains only 6-methylaminopurine. In other words, the 6-methylaminopurine sites have already been filled up in vivo, so that when an enzyme which can make both bases is exposed to this DNA in vitro, then you fill up all the $C$ sites which can be methylated. What we're saying is that what we get in vitro is the mirror image of what you should find in vivo.

Dr. Kornberg: In mentioning that Tween had this effect on the methylation reaction by the T2 methylase, would you say whether it affects the rate or the extent of reaction, or both? And did you imply that its function in the absence of any extraneous lipopolysaccharide that you've introduced might be due to some endogenous factor of that kind?

Dr. Gold: Yes, we originally observed this effect with a very highly purified T2 methylase. When incubated with T2 DNA, absolutely no activity was found. With a little bit of Tween 80 added, the reaction took off and proceeded quite linearly for several days, as a matter of fact. We finally got a preparation in which $20 \%$ of all the available adenines in the T2 DNA which we used became methylated.

Now, with other DNA's the effect is not that striking. The question as to whether the lipopolysaccharide is present in the enzyme or the DNA, is difficult to answer, because if we increase the DNA substrate concentration, we can start getting activity without having to add Tween, and the same is true if we add more enzyme; it appears that it is probably present both in DNA and in the enzyme preparation. If we add exogenous lipopolysaccharides, we can overcome the inhibition simply by increasing either the DNA or the enzyme concentration. Magnesium ions can also overcome the lipopolysaccharide inhibition.

Dr. Bernard Tunik: Do you have any information in your data which would lead you to suspect that the methylation might stabilize the DNA? For example, are there changes in melting point or changes in the frequency of mutation?

Dr. Gold: There are reports, of course, that introducing many 6-methylaminopurine groups in DNA lowers the melting point and vice versa for 5-methyl C, but in most of the cases we've studied the amount of methylation is quite low, and we haven't been able to pick up any really great differences in the stability. It may be that the 6-methylaminopurine has a tendency to weaken the double-stranded structure and 5-methylcytosine would have a tendency to strengthen it, but we have no information on it.

Dr. Leonard Garren: Considering the difference in the methylation of the newly synthesized DNA by the DNA polymerase as compared to the ability to methylate the template, does this mean to you that methylation or the ability to methylate DNA is highly dependent on the actual structure rather than on base composition or base ratio sequence?

Dr. Gold: It may have something to do with the peculiar structure of the DNA polymerase product but I think if we look at it more simply, what we interpret as being the "right sequence" is there in the template DNA. It's just that the sites have already been filled up and with the particular enzyme we used we couldn't get any more in. With other enzymes those DNA's worked perfectly well, so the sites are there but the W enzyme doesn't recognize them. 
Dr. William Bradbury: I was wondering how you would explain the enhancement of Sam'ase activity with ultraviolet-treated T3 on E. coli B?

Dr. Gold: This enhancement or lack of "shut-off" of an early enzyme in phageinfected cells seems to be true for a lot of phages when they are ultraviolet-inactivated. No one knows why the activity doesn't shut off. It has been argued that the replication of the phage DNA is necessary to shut off or to produce the necessary signal to allow these enzymes to shut off; since when you use ultraviolet-inactivated phage, they don't make DNA, there is no signal. 